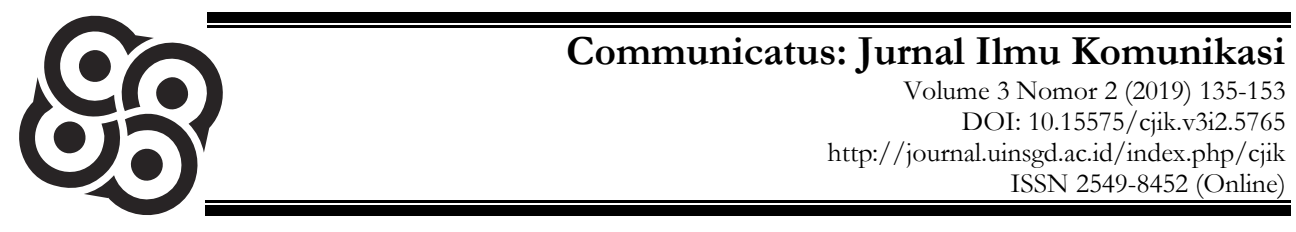

\title{
Gaya Komunikasi Dosen dalam Pembelajaran Mahasiswa
}

\author{
Mutawakki1 $^{1 *} \&$ Nuraedah $^{2}$ \\ ${ }^{12}$ Universitas Tadulako Palu \\ *email.mutawakkil@untad.ac.id
}

\begin{abstract}
This study aims to analyze the communication style in overcoming the boredom of learning in Social History courses in History Education students. The research emphasizes a qualitative approach, which involves 2 lecturers, one lecturer as an observer and one lecturer acting as a direct participant, while the sample is 45 students in class $A$. The results of the research show that in overcoming the saturation of the scholarship, the lecturer develops an active communication style but still prioritizing assertiveness, taking full social initiative so students can imitate, able to integrate with their social environment, able to express their opinions emotionally but in control; sending full information attentively; rule but show firmness, and attention. In addition, lecturers have imperfect Emotive style of communication, Director style that is less established, Reflective style, and has a careful. The impact of this research is expected to contribute academically in implementing strategies and communication styles in the process of transmitting knowledge.
\end{abstract}

Keywords : communication style, boredom learning, social history course

\begin{abstract}
ABSTRAK
Penelitian ini bertujuan untuk menganalisis gaya komunikasi dalam mengatasi kejenuhan belajar pada matakuliah Sejarah Sosial mahasiswa Pendidikan Sejarah. Penelitian menekankan pada pendekatan kualitatif, yang melibatkan 2 orang dosen, satu dosen sebagai pengamat dan satu dosen bertindak sebagai partisipan langsung, adapun sampel adalah mahasiswa sebanyak 45 orang di kelas A. Hasil penelitian menunjukkan bahwa dalam mengatasi kejenuhan belajar, dosen mengembangkan gaya komunikasi aktif, namun tetap mengedepankan ketegasan, mengambil secara penuh inisiatif sosial agar mahasiswa dapat meniru, mampu mengintegrasikan dengan lingkungan sosialnya, mampu menyatakan pendapatnya secara emosional namun terkontrol, mengirim informasi dengan penuh perhatian, memerintah tapi menunjukkan ketegasan, dan perhatian. Selain itu, dosen memiliki gaya komunikasi Emotive style tidak sempurna, Director style yang kurang mapan, Reflektive style, dan memiliki gaya supportive style hati-hati. Gaya komunikasi dosen dalam pembelajaran akan berdampak pada aktualisasi dan implementasi kehidupan sosialnya.
\end{abstract}

Kata kunci : gaya komunikasi, kejenuhan belajar, mata kuliah sejarah sosial 


\section{PENDAHULUAN}

Upaya mencapai output pendidikan yang baik, diperlukan input melalui proses yang bersinergi. Selanjutnya upaya tersebut dalam pendidikan di Indonesia disebut sebagai proses memanusiakan manusia. Konsep pendidikan di Indonesia adalah membentuk manusia seutuhnya, yakni manusia yang memiliki kecerdasan spiritual, kecerdasan emosional dan kecerdasan intelektual melalui proses pembelajaran. Kegiatan pembelajaran menanamkan 3 (tiga) aspek penting yaitu; aspek kognitif, afektif dan psikomotor. Ketiga aspek ini harus mencapai keberhasilan melalui interaksi dalam pembelajaran sesuai tujuan pembelajaran yang hendak dicapai.

Proses mencapai tujuan pembelajaran, maka dosen harus mampu menciptakan pembelajaran yang aktif, kreatif dan menyenangkan. Metode harus sesuai dengan materi pembelajaran yang akan membuat mahasiswa mudah memahami dan mencerna materi yang disajikan. Selanjutnya jika pembelajaran yang dilaksanakan dalam kelas monoton dan tidak menarik perhatian mahasiswa, maka akan membuat mahasiswa menjadi sulit belajar yang akhirnya mendatangkan kejenuhan belajar.

Kesulitan belajar adalah salah satu gejala yang nampak pada mahasiswa yang ditandai dengan prestasi belajar yang lebih rendah dibandingkan dengan mahasiswa yang lainnya, bahkan prestasi belajar jauh lebih rendah dari pada sebelumnya. Mahasiswa yang mengalami kesulitan belajar akan menghambat proses belajar mereka, yang pada akhirnya mendatangkan kejenuhan belajar, sehingga membuat prestasi belajar mereka menjadi menurun. Kejenuhan belajar membuat mahasiswa menjadi malas belajar dan sulit berkonsentrasi, sehingga berdampak pada menurunnya daya serap mahasiswa terhadap materi dan berimbas kepada menurunnya prestasi belajar atau tidak adanya peningkatan prestasi sesuai yang diharapkan dalam proses pembelajaran (Sugihartono, 2007: 81).

Sejarah adalah ilmu yang bersifat banyak hafalan dengan materi yang cukup banyak. Pemikiran negatif tentang sejarah berkembang bahwa sejarah hanya menghafal tanggal dan nama belaka. Ini semakin membuat matakuliah sejarah, tidak banyak diminati. Namun berbeda dengan mahasiswa di Program Studi Pendidikan Sejarah yang memang menggeluti bidang ilmu ini. Namun, mengapa matakuliah menghafal sejarah seperti beban besar bagi kebanyakan mahasiswa? Barangkali karena menghafal tanggal dan nama dalam sejarah tidak banyak bersentuhan dengan kehidupan mereka setelah memasuki dunia kerja diluar sebagai guru. Faktor penyebab lain dapat diihat dari gaya komunikasi dosen yang mengajar. Apalagi jika kegiatan pembelajaran tidak menyenangkan, kurang variatif atau hanya menggunakan metode ceramah dan tanya jawab. 
Kurang pahamnya terhadap manfaat pembelajaran sejarah membuat mahasiswa tidak termotivasi belajar sejarah. Hal inilah yang membuat mahasiswa mengalami kejenuhan belajar. Kejenuhan belajar yang dialami oleh mahasiswa ini berdasar hasil observasi dan hasil wawancara di lapangan, salah satu penyebabnya adalah gaya komunikasi dosen dalam matakuliah sejarah masih dianggap kurang optimal.

Hasil observasi awal sebanyak 2 kali yang dilakukan peneliti pada bulan September 2016 terhadap matakuliah Sejarah Sosial di Kelas A dan wawancara yang dilakukan peneliti kepada dosen dengan Kode NU, pada bulan September 2016, maka ditemukan hambatan belajar disebabkan oleh kejenuhan belajar yang dialami beberapa mahasiswa tersebut. Unit analisis subyek terhadap 45 orang mahasiswa, dengan pendekatan studi kasus sebanyak 9 orang. Dari 45 (Empat Puluh Lima) mahasiswa, terdapat 9 (Sembilan) mahasiswa yang mengalami kejenuhan belajar, terlihat dengan beberapa aktivitas yang tidak mendukung proses belajar mereka seperti bercerita dengan teman saat dosen sedang memberikan materi pelajaran (1 orang), bermain handphone (2 orang), mencoret-coret kertas (1 orang), dan mengerjakan tugas matakuliah lain (2 orang). Selain 5 mahasiswa yang menunjukkan aktivitas kejenuhan di dalam kelas, ada 2 mahasiswa yang tidak hadir ketika proses pembelajaran berlangsung. Ketidakhadiran mahasiswa tersebut merupakan indikasi bahwa mereka jenuh terhadap matakuliah sejarah yang tiap hari diskusi dan tanya jawab saja.

Bercerita dengan teman sebangku saat dosen sedang menyajikan materi sangat mengganggu konsentrasi belajar mahasiswa lain. Mahasiswa yang melakukan hal tersebut dalam proses pembelajaran, dosen mengambil tindakan dengan menegur langsung. Setelah ditegur, mahasiswa tersebut diam dan mendengarkan kembali materi yang disampaikan, namun beberapa saat kemudian mahasiswa tersebut kembali bercerita dengan teman sebangku. Adapun mahasiswa yang membuka HP, HP-nya untuk sementara diambil, setelah matakuliah berakhir dikembalikan dengan memberikan pembinaan dan teguran. Selain itu, adapula mahasiswa yang mencoret-coret kertas dan meja. Inipula mendapat perhatian khusus. Namun teguran dan pembinaan yang dilakukan pada hari itu akan mengulang kembali tindakannya di pertemuan berikut.

Penelitian yang berkaitan dengan topik di atas pernah dilakukan oleh Hutapea (2016). Penelitian menunjukkan bahwa komunikasi merupakan aspek penting yang dibutuhkan oleh manusia. Sebagai makhluk sosial siapapun dihadapkan dengan proses interaksi yang menekankan keterampilan komunikasi dan kontak sosial. Pada praktiknya, proses komunikasi tersebut dihadapkan dengan beragam permasalahan yang menuntut adanya pola dan gaya komunikasi tertentu, sehingga tujuan dari komunikasi yang diinginkan dapat tercapai, baik oleh komunikator maupun komunikan. Penelitian Setyanto (2012) menunjukkan 
bahwa gaya kepemimpinan dan gaya komunikasi berpengaruh terhadap iklim komunikasi dalam sebuah organisasi. Komunikasi dapat meningkatkan kepuasaan komunikasi anggota. Kepuasaan komunikasi dapat pula meningkatkan kinerja dan performa organisasi. Gaya komunikasi memiliki pengaruh terhadap kualitas layanan dan kepuasaan. Gaya komunikasi diukur menggunakan indikator posisi tubuh, kontak mata, ekspresi wajah, dan intonasi suara. Indikatorindikator tersebut menunjukkan pengaruh signifikan terhadap kepuasaan nasabah dan meningkatkan performa organisasi (Mazaya, Setiabudi, \& Santosa, 2013). Selain itu, gaya komunikasi juga dapat dijadikan sebagai ruang pengungkapan diri. Kemampuan komunikasi dan kepemimpinan akan mewujudkan efektifitas organisasi (Teviana, 2011).

Komunikasi, lisan dan nonverbal, dalam suatu kelompok adalah sesuatu yang khas dari kelompok dan sifatnya unik. Sulitnya menemukan artikel terkait gaya komunikasi dalam mengatasi kejenuhan belajar mendorong menelusuri penelitian terkait gaya belajar dikaitkan dengan kejenuhan belajar mahasiswa (Giri, 2006).

She dan Fisher mengkategorikan lima pola komunikasi dalam proses belajar-mengajar, sebagai berikut: Challenging (Menantang), Challenging yaitu gaya bertanya untuk meningkatkan kemampuan peserta didik dalam memahami materi tertentu, Encouragement and praise (Memotivasi dan Memuji) Interaksi ini berhubungan dengan sejauh mana guru tersebut memuji dan mendorong mahasiswa menjadi lebih baik didalam ruang kelas. Pujian dapat meningkatkan motivasi, yang mungkin diberikan oleh dorongan guru atau pujian mahasiswa, serta meningkatkan minat dan keterlibatan di kelas, Non-verbal support (dukungan non-verbal) mengacu kepada sejauh mana guru menggunakan komunikasi non verbal untuk berinteraksi secara positif dengan mahasiswa, Understanding and friendly (memahami dan bersahabat) Pola ini mengacu pada bagaimana guru memahami dan bersikap bersahabat terhadap mahasiswa, dan Controlling (mengontrol) yakni pola komunikasi kelima ini berhubungan dengan bagaimana guru mengendalikan dan mengelola perilaku mahasiswa di kelas (Mahanani, 2014: 60)

Komunikasi antarpribadi yang interaktif tersebut mengandalkan gaya berkomunikasi yang dihubungkan dengan nilai-nilai yang dianut orang. Banyak tipe atau gaya personal yang dimiliki manusia dalam melakukan proses komunikasi. Gaya komunikasi personal dapat ditunjukkan dengan cara kognitif maupun sosial. Komunikasi yang terjadi antara seseorang dengan orang lain ini, berlangsung pada taraf kedalaman yang berbeda-beda. Gaya komunikasi setiap orang tentunya berbeda-beda dan memiliki ciri khas tersendiri. Dengan terpaan media sosial, tentu tidak menutup kemungkinan memengaruhi gaya komunikasi 
sehari-hari dari pengguna media sosial tersebut di kehidupan nyata. Contohnya adalah gaya komunikasi Sujiwo Tedjo di twitter dengan ciri khas "urakan" yang follower-nya mencapai ribuan. Beberapa dari follower Sujiwo Tedjo yang tergolong ABG (Anak Baru Gede) ikut menggunakan gaya komunikasi tersebut karena dinilai lebih membumi apabila diaplikasikan di kehidupan nyata (Mahanani, 2014: 60).

Hal ini diperkuat dengan teori bahwa, gaya komunikasi merupakan cara yang digunakan komunikator dalam menyampaikan pesan. Setiap komunikator mempunyai gaya komunikasi dan ciri khas berbeda-beda. Perbedaan ini dapat dilihat dari segi budaya, pendidikan, lingkungan keluarga, pengalaman dan lain sebagainya. Hasil penelitian yang dilakukan oleh Arifin (2018) yang menunjukkan bahwa strategi komunikasi dakwah yang digunakan dalam masyarakat yang multikultural dengan cara pendekatan multikulturalisme dalam dakwah, yakni berusaha untuk mencapai dua hal, yaitu titik temu dalam keragaman, dan toleransi dalam perbedaan. Tulisan ini dapat menjadi pembanding bahwa strategi komunikasi juga perlu apabila mengajar dengan komunitas yang beragam etnis dengan melihat unsur keragaman dan toleransi dalam perbedaan di kelas A, mulai beragam agama, budaya dan etnis.

Persoalan pengimplementasian strategi yang harus selalu diingat bahwa sebaik apapun rumusan strategi, hanya akan menjadi retorika belaka jika tidak dapat diimplementasikan dengan baik. Oleh karena itu, agar perusahaan dapat mencapai tujuan secara optimal, maka selain harus mampu merumuskan strategi (Sudarman, 2018).

Gaya komunikasi ada tiga yaitu: Gaya komunikasi Asertif, non asertif dan agresif. Gaya komunikasi Asertif ialah gaya ini memiliki ciri mampu mengekspresikan perasaan dan harga diri berdasarkan pikiran yang etis. Sehingga dalam mengekspresikan diri dengan memberi perhatian, martabat dan rasa hormat. Gaya non asertif lebih menunjukkan pada perasaan takut dan bimbang, mengingkari diri, serta lebih memberikan keuntungan pada orang lain. Gaya Agresif ialah Gaya ini berusaha mendominasi dalam interaksi dengan orang lain baik verbal maupun non verbal. Gaya ini sangat tidak efektif karena ada pemaksaan hak orang lain. Tiga macam gaya komunikasi antara lain: non assertive ditandai dengan kecenderungan untuk menyembunyikan atau berdiam diri apabila terdapat suatu masalah. Hal tersebut mendorong individu untuk memilih berdiam diri dari pada memicu keramaian demi terciptanya perdamaian, assertive merupakan sebuah gaya yang ditandai dengan menyatakan opini secara langsung atau terbuka agar tujuan orang tersebut terpenuhi, agresive adalah gaya komunikasi yang ditandai dengan usaha individu untuk selalu hadir atau mendekatkan diri disetiap kesempatan (Hutapea, 2016).

Adanya penerapan gaya komunikasi guru yang menyenangkan, secara tidak langsung hal ini dapat juga menumbuhkan semangat atau motivasi belajar 
mahasiswa terhadap suatu mata pelajaran. Motivasi belajar yang timbul dalam diri mahasiswa disebabkan karena adanya cita-cita atau dorongan untuk memperoleh hasil yang diharapkan (Sucia, 2016).

Pendidikan adalah komunikasi dalam arti bahwa, dalam proses tersebut terlibat dua komponen, yang terdiri atas manusia, yakni pengajar sebagai komunikator dan pelajar sebagai komunikan. Lazimnya, pada tingkatan bawah dan menengah pengajar itu disebut guru, sedangkan pelajar itu disebut murid, pada tingkatan tinggi pengajar itu dinamakan dosen, sedangkan pelajar dinamakan mahasiswa. Pada tingkatan apa pun, proses komunikasi antara pengajar dan pelajar itu pada hakikatnya sama saja. Perbedaannya hanyalah pada jenis pesan serta kualitas yang disampaikan oleh dosen kepada mahasiswa. Perbedaan antara komunikasi dengan pendidikan terletak pada tujuannya atau efek yang diharapkan. Ditinjau dari efek yang diharapkan, tujuan komunikasi sifatnya umum, sedangkan tujuan pendidikan sifatnya khusus. Kekhususan inilah yang dalam proses komunikasi melahirkan istilah-istilah khusus seperti penerangan, propaganda, indoktrinasi, agitasi, dan pendidikan. Tujuan pendidikan adalah khas, yakni meningkatkan pengetahuan seseorang mengenai suatu hal sehingga ia menguasainya (Sucia, 2016).

Tulisan ini mengambil beberapa indikator yang perlu ditelusuri termasuk kejenuhan belajar. Kejenuhan memiliki akar kata jenuh. Kejenuhan berarti padat atau penuh sehingga tidak mampu lagi memuat apapun. Selain itu, jenuh juga bisa berarti jemu atau bosan. Kejenuhan belajar adalah rentang waktu tertentu yang digunakan untuk belajar, tetapi tidak mendatangkan hasil. Kejenuhan belajar mengakibatkan mahasiswa mampu menerima pelajaran bahkan tidak dapat memuat intisari dari pembelajaran tersebut (Tohirin, 2009:130).

Kejenuhan belajar merupakan salah satu kesulitan belajar yang dialami mahasiswa di mana mereka merasa seakan-akan pengetahuan dan kecakapan yang diperoleh dari belajar tidak mengalami kemajuan. Hal ini disebabkan sistem akalnya tidak dapat memproses informasi-informasi atau pengalaman baru sehingga mereka merasa proses belajarnya tidak mengalami kemajuan (Syah, 2011: 181). Kejenuhan belajar adalah kondisi mental seseorang saat mengalami rasa bosan dan lelah yang amat sangat sehingga mengakibatkan timbulnya rasa enggan, lesu dan tidak bersemangat melakukan aktivitas belajar (Hakim, 2004: 62). Mahasiswa yang mengalami kesulitan belajar ditandai dengan prestasi belajar yang lebih rendah dibandingkan dengan mahasiswa lainnya bahkan prestasi belajar saat ini jauh lebih rendah dibanding yang sebelumnya (Sugihartono (2007: 149), dengan demikian, yang dimaksud dengan kejenuhan belajar adalah suatu kondisi pada saat mahasiswa merasa bosan, lelah, tidak bersemangat belajar dan kurang perhatian, serta tidak mengalami kemajuan dalam belajar. 
Ada lima faktor penyebab kejenuhan belajar yaitu: cara atau metode belajar yang tidak bervariasi; cara atau metode belajar merupakan hal yang sangat penting dalam proses pembelajaran untuk mengarahkan konsentrasi anak serta menciptakan suasana belajar yang menyenangkan oleh sebab itu cara atau metode belajar sebaiknya bervariasi agar pembelajaran tidak bersifat monoton dan gairah belajar anak meningkat, belajar hanya di tempat tertentu; tempat belajar mahasiswa umumnya di dalam kelas, namun guru harus kreatif menggunakan tempat belajar sebagai media dan sumber belajar.

Suasana belajar yang menyenangkan dan bersifat fleksibel perlu diterapkan dalam proses pembelajaran agar anak tidak mudah jenuh dan membuat mahasiswa menjadi leluasa berpikir, bertanya dan berinteraksi dengan guru dan mahasiswa dalam proses pembelajaran, kurangnya aktivitas rekreasi atau hiburan; saat mahasiswa mulai merasa bosan dalam proses pembelajaran apalagi waktu belajar di siang hari maka dosen perlu selingi kegiatan pembelajaran dengan rekreasi atau hiburan untuk mengusir kejenuhan belajar mahasiswa.

Kurangnya aktivitas rekreasi atau hiburan di kelas membuat mahasiswa mendatangkan kebosanan dan ketegangan belajar mahasiswa bahkan akan membuat mahasiswa mengantuk sehingga membuat mereka sering keluar kelas; adanya ketegangan mental kuat dan berlarut-larut pada suasana belajar; suasana belajar yang tidak menyenangkan akan membentuk persepsi mahasiswa bahwa belajar sangat menegangkan dan berat dilakukan. Padahal suasana itu dapat diubah dengan strategi pembelajaran yang variatif dan menyenangkan mahasiswa. Perasaan tidak nyaman saat belajar membuat mahasiswa tidak dapat menyadari pentingnya belajar. Oleh sebab itu, mental anak perlu ditempa dalam proses pembelajaran yang menyenangkan (Hakim, 2004: 63-65).

Sedangkan Faktor-faktor yang menyebabkan kejenuhan belajar adalah; terlalu lama waktu untuk belajar tanpa kurang istirahat, belajar secara rutin atau monoton tanpa variatif, lingkungan belajar yang buruk atau tidak mendukung proses pembelajaran. Begitu pula gaya belajar yang berpusat pada dosen, membuat mahasiswa dapat merasa jenuh, karena mahasiswa tidak diberi kesempatan dalam menjelaskan atau menyampaikan pendapat mereka, Tidak adanya minat mahasiswa dalam belajar juga dapat meyebabkan kejenuhan belajar terhadap mata pelajaran itu (Syah, 1999:164).

Uraian di atas dapat menggambarkan kesimpulan bahwa lingkungan belajar dan metode pembelajaran dapat mengakibatkan kejenuhan belajar. Lingkungan belajar yang kurang nyaman dan metode pembelajaran yang tidak tepat dan tidak bervariasi dapat menyebabkan kejenuhan belajar, begitupula sebaliknya, lingkungan belajar yang nyaman dan metode pembelajaran yang tepat serta bervariasi dapat membuat suasana belajar menjadi menyenangkan.

Indikator kejenuhan belajar mahasiswa adalah; mahasiswa dikatakan mengalami kejenuhan belajar jika terlihat gejala: fisik terlihat letih dan lemas, 
malas belajar, sering sakit saat proses pembelajaran, merasa bosan, bingung, suka mengganggu teman, bercerita dengan teman sebangku, dan melakukan aktivitas lain saat pembelajaran (mencoret-coret, menggambar atau mempelajari pelajaran lain, bermain HP). Ada beberapa metode untuk mencegah dan mengatasi kejenuhan belajar, yaitu: belajar dengan metode yang bervariasi, mengadakan perubahan fisik di ruang belajar, menciptakan situasi baru di ruang belajar, melakukan aktivitas rekreasi dan hiburan, hindarkan ada ketegangan mental saat belajar (Hakim, 2004: 66-69). Untuk mengatasi fenomena kejenuhan belajar pada mahasiswa maka guru dituntut menggunakan metode pembelajaran yang lebih variatif dan tidak monoton seperti gaya konvensional. Agar pembelajaran efektif dan mendapatkan hasil yang baik maka guru harus menyiapkan strategi pembelajaran yang baik pula dan dapat mengatasi kejenuhan belajar mahasiswa (Mulyono, 2011: 9).

Kejenuhan belajar dapat dialami oleh beberapa anggota tubuh seperti kaki, jari-jari tangan, lengan, tegangan otot dan lain-lain. Masalah tersebut dapat diatasi dengan cara: istirahat/ tidur yang cukup, mengurangi aktivitas di malam hari sehingga tidak menyebabkan begadang, mengonsumsi makanan bergizi, dan memijat bagian yang lelah atau menggunakan obat tertentu untuk melancarkan sirkulasi darah (Rumini, 1998: 31).

Matakuliah yang menjadi sorotan disini adalah Sejarah Sosial. Berbagai aspek kehidupan dapat dipelajari dalam sejarah. Dalam pembelajaran sejarah, mahasiswa diharapkan dapat merekonstruksi secara langsung suatu kehidupan yang telah terjadi di suatu peristiwa lewat benda-benda peninggalan yang secara nyata dapat disaksikan sekarang (Nuraedah, 2017: 1).

Sejarah sosial, sering disebut pula dengan sebutan sejarah sosial baru, yakni bidang atau kajian sejarah yang mengkaji pengalaman hidup pada masa lalu. Pada "masa keemasan" sejarah sosial, di mana bidang ini merupakan bidang utama pada 1960-an dan 1970-an di antara para sarjana, dan masih banyak dikaji di departemen sejarah di Britania, Kanada, Prancis, Jerman, dan Amerika Serikat. Pada dua dekade dari 1975 sampai 1995, proporsi profesor sejarah di universitas Amerika yang memiliki spesialisasi di bidang sejarah sosial naik dari 31\% menjadi 41\%, sedangkan proporsi sejarawan politik turun dari 40\% ke 30\% (Haber at all, 1997: 34043).

Tujuan penelitian untuk menganalisis gaya komunikasi dalam mengatasi kejenuhan belajar pada matakuliah Sejarah Sosial mahasiswa Pendidikan Sejarah di FKIP Untad. Hasil penelitian diharapkan memiliki manfaat bagi pengembangan program Studi Pendidikan Sejarah dalam melihat mahasiswa, selain itu, menjadi bahan referensi bagi penelitian selanjutnya dengan melihat dari aspek yang lain. 
Penelitian ini menekankan pada pendekatan kualitatif dengan meneliti 1 orang dosen yang sekaligus bertindak sebagai partisipan dalam penelitian dan 45 orang mahasiswa di kelas A. Sementara yang di teliti adalah dosen NU sekaligus sebagai peneliti partisipan dengan observer utama adalah ketua tim peneliti, dan yang melakukan penelitian ini adalah 1 dosen yang tidak mengampu matakuliah Sejarah Sosial dan 1 (satu) dosen selaku pengampu matakuliah Sejarah Sosial. Pemilihan dua (dua) orang dosen dengan pertimbangan matakuliah Sejarah Sosial banyak diampu oleh dosen NU, 14 kali pertemuan dengan kredit matakuliah 2 SKS dan ketua tim selaku instrumen utama. Penelitian menggunakan dua sumber, yaitu sumber primer dan sekunder. Sumber primer didapat dari hasil observasi dan wawancara, sedangkan sumber sekunder didapat dari buku, jurnal, dan juga penelusuran internet. Lokasi penelitian di Program Studi Pendidikan Sejarah FKIP Universitas Tadulako di Jalan Soekarno Hatta, KM 09.

Analisis data dalam penelitian ini menggunakan pendekatan kualitatif yang merujuk kepada Miles dan Huberman (2009), dengan tiga analisis meliputi: reduksi data, display data dan verifikasi. Reduksi data dilakukan agar data yang diperoleh merupakan data yang benar-benar valid, selanjutnya peneliti mengumpulkan data yang sudah tersedia, mengelompokkan data-data yang tersedia untuk selanjutnya disatukan sesuai dengan kebutuhan penelitian. Penyajian data dilakukan dalam bentuk deskriptif. Penulis melakukan interpretasi terhadap data yang diperoleh, kemudian melakukan verifikasi data, atau menarik kesimpulan terhadap data yang diperoleh dari hasil penelitian dan pembahasan yang telah di analisis.

\section{HASIL DAN PEMBAHASAN}

Gaya komunikasi merupakan cara yang digunakan komunikator dalam menyampaikan pesan. Setiap komunikator mempunyai gaya komunikasi dan ciri khas berbeda-beda. Perbedaan ini dapat dilihat dari segi budaya, pendidikan, lingkungan keluarga, pengalaman dan lain sebagainya. Hasil di lapangan menunjukkan karena faktor budaya, pendidikan dan keluargalah yang menjadi salah satu dari sekian alternatif penemuan masalah (Mahanani, 2014). Pengalaman dan latar belakang pendidikan Dosen sebagai komunikator, ikut menentukan terhadap gaya komunikasi dalam pembelajaran mahasiswa.

Praktek komunikasi di dalamnya terdapat empat gaya komunikasi sebagai berikut: Emotive style, yang menggambarkan gaya komunikasi seseorang selalu aktif namun lembut, mengambil inisiatif sosial, merangkum dengan, menyatakan pendapat secara emosional. Director style, yang menyampaikan pendapatnya sebagai orang sibuk, kadang-kadang mengirimkan informasi tetapi tidak memandang orang lain, yang tampil dengan sikap serius dan suka mengawasi orang lain. Reflektive style, suka mengontrol ekspresi emosi mereka, menunjukkan 
pilihan tertentu, cenderung menyatakan pendapat dengan terukur, dan melihat kesulitan yang harus ketahui. Serta Supportive style, diam dan tenang penuh perhatian, melihat orang dengan perhatian penuh, cenderung menghindari kekuasaan, dan dia membuat keputusan dengan mempertimbangkan semua pihak (Liliweri, 2011: 311).

\section{Gaya Komunikasi Dosen dalam Mengajar}

Masing-masing gaya komunikasi memiliki tujuan yang berbeda-beda, yakni bersifat mendukung, memerintah, mengkoordinasi, dan memotivasi yang sesuai dengan realitas kepribadian seseorang pada umumnya. Beberapa gaya komunikasi ini memengaruhi pola belajar, proses transfer pengetahuan dan kesadaran berperilaku mahasiswa dalam mendalami dan merefleksikan nilai-nilai pengetahuan yang didapatkan pada proses perkuliahan.

Gaya komunikasi berkaitan erat dengan proses pendekatan yang dilakukan dosen terhadap mahasiswa, masing-masing dosen memiliki strategi tertentu ketika melakukan komunikasi dalam perkuliahan. Masing-masing dosen memiliki pengetahuan dan pengalaman dalam melakukan proses perkuliahan, mereka juga memiliki indikator di luar panduan yang telah ditetapkan Perguruan Tinggi, sehingga akan berdampak pada perbedaan dan khas dosen dalam mengirim ilmu pengetahuan. Gaya Komunikasi dosen berdasar hasil observasi dan wawancara dapat dilihat dalam tabel berikut.

Tabel 1. Hasil Pengamatan Gaya Komunikasi Dosen Matakuliah Sejarah Sosial di Program Studi Pendidikan Sejarah FKIP Untad.

\begin{tabular}{|c|c|c|}
\hline $\begin{array}{l}\text { Item } \\
\text { Observasi }\end{array}$ & $\begin{array}{l}\text { Deskriptor/Tanggapan Hasil } \\
\text { Pengamatan }\end{array}$ & Keterangan \\
\hline Emotive style & $\begin{array}{l}\text { Dosen aktif, mengedepankan inisiatif } \\
\text { dan emosional, terukur dengan } \\
\text { kondisi. }\end{array}$ & $\begin{array}{l}\text { Cenderung penekanan tegas dengan } \\
\text { aura membawa anak untuk mandiri.. }\end{array}$ \\
\hline Director style & $\begin{array}{l}\text { Selalu mengawasi gerak-gerik } \\
\text { mahasiswa sebagai bagian dari } \\
\text { pengolahan kelas. }\end{array}$ & $\begin{array}{l}\text { Penyampaian informasi dilakukan } \\
\text { dengan memandang mahasiswa. }\end{array}$ \\
\hline Reflektive style & $\begin{array}{l}\text { Mengarahkan mahasiswa } \\
\text { mengerjakan tugas dengan ekspresi } \\
\text { penekanan wajib dikerjakan sesuai } \\
\text { aturan keilmuan. Menyampaikan } \\
\text { pendapat terhadap kekeliruan } \\
\text { mahasiswa }\end{array}$ & $\begin{array}{l}\text { Setiap tugas mahasiswa diberikan } \\
\text { umpan balik sebagai hasil refleksi. }\end{array}$ \\
\hline Supportive style & $\begin{array}{l}\text { Sikap diam dan tenang tidak nampak } \\
\text { selama pembelajaran matakuliah } \\
\text { Sejarah Sosial berlangsung. }\end{array}$ & $\begin{array}{l}\text { Support terhadap penilaian akhir } \\
\text { dengan mempertimbangkan semua } \\
\text { aspek. }\end{array}$ \\
\hline
\end{tabular}

Sumber: Hasil Observasi di Kelas A. 
Hasil observasi tersebut menunjukkan berbagai macam gaya komunikasi, komunikator memilih untuk menggunakan gaya komunikasi yang tepat agar dalam menyampaikan pesan memperoleh tanggapan yang positif sehingga materi yang disajikan mudah diterima dengan baik. Pemilihan gaya komunikasi yang tidak tepat menimbulkan gambaran buruk dibenak mahasiswa sehingga hasil yang diinginkan bukan tidak mungkin tidak tercapai dengan maksimal. Gaya komunikasi yang nampak di atas adalah gaya Emotive style tidak sempurna, Director style yang kurang mapan, Reflektive style, dan memiliki gaya supportive style hati-hati.

\section{Gaya Komunikasi Dosen dalam Mengatasi Kejenuhan Belajar Mahasiswa}

Matakuliah Sejarah Sosial telah diupayakan semaksimal mungkin diterapkan dengan baik oleh dosen yang mengajar mata pelajaran tersebut. Hasil wawancara menunjukkan bahwa matakuliah Sejarah Sosial sudah menggunakan beberapa metode seperti cooperative learning, ceramah, tanya jawab dan unjuk kerja. Namun yang banyak digunakan adalah metode diskusi.

Hasil observasi juga menunjukkan bahwa di awal suasana pembelajaran Sejarah Sosial cukup kondusif namun lebih dari sejam kemudian beberapa mahasiswa sudah mulai menunjukkan sikap kejenuhan belajar. Berdasarkan hasil observasi ada hal yang kadang dilupakan dosen ketika mengajar adalah gaya komunikasi dosen yang bisa menyebabkan mahasiswa mengalami kejenuhan belajar. Mahasiswa tersebut belum memperoleh sentuhan gaya komunikasi maksimal dari dosen yang bersangkutan.

Dosen sudah berupaya semaksimal mungkin, namun tetap membutuhkan proses dan inovasi untuk membuat pembelajaran lebih menarik lagi. Melalui penelitian ini, terdapat problematik yang dihadapi dosen dan mahasiswa dalam matakuliah Sejarah Sosial. Mempertimbangkan hasil penelitian tersebut maka peneliti menyarankan beberapa hal: dalam pembelajaran ini, dosen dituntut memberikan gaya komunikasi yang tepat sebagai bentuk pemahaman mendalam kepada mahasiswa mengenai tujuan matakuliah Sejarah Sosial bagi kehidupan dan masa depan mereka ketika bergaul dengan lingkungan di luar lingkungan sekolah dengan banyaknya permasalahan di masyarakat, dosen sebaiknya menambah metode pembelajaran dan mengemas dalam bentuk yang lebih menarik lagi, agar mahasiswa tidak cepat merasa jenuh dan tidak mengantuk saat belajar, terlebih lagi jika pembelajaran dilaksanakan di siang hari. Dosen harus peka dan ada perhatian lebih kepada mahasiswa yang mengalami kejenuhan belajar. Hal yang ditakutkan nantinya dengan kejenuhan belajar mereka tidak termotivasi lagi untuk belajar.

Sesuai hasil wawancara dan hasil observasi diidentifikasi beberapa sikap mahasiswa yang menunjukkan kejenuhan belajar yakni: bercerita dengan teman sebelahnya; mengganggu teman lainnya; membuka HP; mencoret-coret kertas; Malas memperhatikan dosen (menghayal) di kelas, menengok terus menerus ke 
luar kelas; dan keluar tanpa izin.

Adapun 9 (sembilan) mahasiswa yang mengalami kejenuhan belajar, terlihat dengan beberapa aktivitas yang tidak mendukung proses belajar mereka seperti bercerita dengan teman sebelahnya sebanyak 1 (satu) orang mengganggu teman lainnya; sebanyak 1 (satu) orang membuka HP sebanyak 1 (satu) orang; mencoret-coret kertas sebanyak 1 (satu) orang; malas memperhatikan dosen (menghayal) di kelas sebanyak 1 (satu) orang; menengok terus menerus ke luar kelas sebanyak 1 (satu) orang; dan keluar tanpa izin sebanyak 1 (satu) orang.

Selain 7 (tujuh) mahasiswa yang menunjukkan aktivitas kejenuhan di dalam kelas, ada 2 mahasiswa yang tidak hadir ketika proses pembelajaran berlangsung. Ketidakhadiran mahasiswa tersebut merupakan indikasi bahwa mereka jenuh terhadap matakuliah sejarah yang tiap hari diskusi dan tanya jawab dan penugasan saja. Kejenuhan belajar mahasiswa tersebut ditunjukkan baik di awal maupun saat-saat akhir pembelajaran. Mahasiswa yang menunjukkan kejenuhan belajar tersebut adalah mahasiswa yang sama sebanyak 9 orang.

Dengan demikian, bahwa mahasiswa dikatakan mengalami kejenuhan belajar jika terlihat gejala: suka menghayal; malas belajar; mata kosong; merasa bosan; bingung; suka mengganggu teman/bercerita dengan teman sebangku; melakukan aktivitas lain saat pembelajaran, mencoret-coret buku, mengerjakan tugas lain, bermain HP, serta absen di kelas (tidak hadir).

Menyikapi hal tersebut diatas, maka peneliti menyarankan beberapa hal untuk menangani mahasiswa yang mengalami kejenuhan belajar matakuliah Sejarah Sosial, yaitu: memperbaiki gaya komunikasi ketika mengajar, melakukan pemisahan kursi secara berjauhan dengan mahasiswa yang ditemani bercerita, pendekatan pribadi kepada mahasiswa yang mengalami kejenuhan, penanganan khusus melalui pendekatan budaya, sosial dan lingkungan terhadap mahasiswa yang mengalami problem yang sama, dengan meningkatkan kepekaan terhadap kondisi mahasiswa yang mungkin belum terima kiriman dari orang tua, atau ada masalah lain, perlu mengemas pembelajaran menjadi lebih menarik dengan melibatkan mahasiswa dalam kegiatan penelitian lapangan di wilayah yang ada hubungannya dengan tema atau materi pada matakuliah Sejarah Sosial.

Beberapa faktor yang menyebabkan kejenuhan belaja berupa; gaya komunikasi dosen dan mahasiswa harus dua arah; mahasiswa lelah karena banyaknya tugas, ada mahasiswa yang butuh perhatian karena faktor ekonomi; suka begadang dan terlibat pergaulan bebas seperti mengkonsumsi rokok tanpa kontrol langsung dari orang tua. Hal ini sesuai dengan pernyataan informan penelitian dalam wawancara: "Beberapa hal yang menjadi penyebab kejenuhan belajar kami dalam hal ini karena dosen tidak memberikan kita kesempatan berkomunikasi secara bebas, kami jadi tegang dan maunya kami, kami di dengar 
juga keluh kesahnya karena jujur saja, saya memiliki kemampuan yang pas dalam belajar sementara dosennya menuntut tugas harus bagus, harus mampu berargumen dengan bagus, bagaimana mengerjakannya sementara saya tidak mampu, mau berkomunikasi dengan dosennya, takut di tolak atau dimarah. Tapi ada juga sih teman yang biasa buat jengkel dosen NU, seperti menegur jangan merokok di dalam kampus, telah berjanji tidak akan melanggar, tetapi di situasi lain kedapatan lagi merokok, ya tentunya dosen NU menegur lagi. Tapi ketegasan dosen kadang memotivasi kami mengerjakan tugas pada waktunya secara mandiri (Wawancara dengan I Made Gunatayasa, 6 Oktober 2016).

Merujuk dari hasil wawancara di atas, sebagaimana hasil observasi sebelumnya memang sangat nampak bahwa dosen masih cenderung emotive style, yang membawa mahasiswa tidak bebas, padahal mahasiswa dalam wawancara di atas membutuhkan penekanan tegas dengan aura membawa anak untuk mandiri. Membawa anak melaksanakan pelaporan melalui sikap mandiri.

Ketika informasi dari mahasiswa tersebut, maka dapat dilihat bahwa dosen pengampu matakuliah tersebut sebagai seorang komunikator di depan mahasiswanya karena faktor budaya dari keluarga yang tidak boleh membantah orang yang lebih tua, karena ada anggapan pammali, melawan orang tua, faktor lingkungan keluarga juga mendukung karena secara lingkungan pengampu matakuliah hidup dari lingkungan keluarga yang berdekatan dengan laut. Jadi harus mengeraskan suara ketika berkomunikasi, dan faktor pendidikan atau didikan orang tua sebagai guru yang lebih konvensional, masih menghargai etika dan sopan santun dalam lingkungannya. Setiap komunikator mempunyai gaya komunikasi dan ciri khasnya masing-masing. Perbedaan ini dapat dilihat dari segi budaya, pendidikan, lingkungan keluarga, serta faktor kemandirian. Hasil di lapangan menunjukkan bahwa, faktor budaya, pendidikan, keluarga, media yang benar, isi pesan dan kemandirian menjadi salah satu dari sekian alternatif penemuan masalah. Komunikan dianggap secara pasif menerima terpaan pesanpesan komunikasi, sehingga dengan menggunakan komunikator yang tepat, pesan yang baik, dan media yang benar, komunikan dapat diarahkan sesuai dengan keinginan (Sudiansyah, 2017).

Seorang mahasiswa yang merasa kurang bisa langsung menerima materi kuliah, karena memiliki kemampuan yang kurang di bawah teman-temannya, sedangkan dosennya menghendaki mahasiswa disiplin, tugas harus dikumpulkan tepat waktu, namun mahasiswa berkeinginan agar mahasiswa diberi kesempatan perpanjangan waktu, walaupun nilainya tidak sama dengan temannya yang sudah mengumpulkan tugas terlebih dahulu. Mahasiswa tersebut juga belum pernah berkomunikasi berdua dengan dosennya, sehingga peluang bercerita tentang kekurangannya tidak tersampaikan. Gaya komunikasi yang aktif perlu diterapkan, namun tetap lembut. Ada sisi positif dari dosen tersebut, yakni sering memotivasi dan menasehati mahasiswa untuk berusaha supaya bisa berubah 
(Wawancara dengan Nita, tanggal 21 September 2016).

Terkait dengan ungkapan informan di atas, ketika disandingkan dengan hasil observasi maka ditemukan fakta yang berkembang bahwa mengarahkan mahasiswa mengerjakan tugas dengan ekspresi wajib dikerjakan dan meminta mahasiswa mengerjakan sesuai kaidah keilmuan, serta menyampaikan pendapat terhadap kekeliruan mahasiswa dalam mengerjakan tugas laporan Sejarah Sosial melalui umpan balik, maka mahasiswa dengan segera akan memperbaiki tugas laporannya apabila ada umpan balik dosen akan mendorong mahasiswa rajin dan dapat mengurangi rasa jenuhnya belajar sejarah sosial.

Informan lain menyatakan bahwa perilaku yang ditampilkan saat proses belajar bertujuan agar mendapatkan perhatian dari dosen yang bersangkutan. Hal ini diungkapkan informan bahwa untuk mendapatkan perhatian dosen beberapa hal yang informan lakukan misalnya menganggu teman yang sedang memperhatikan, ngobrol saat pembelajaran, melakukan aktifitas lain di luar proses pembelajaran saat dalam kelas, dan lain-lain. Namun di luar itu, informan menyatakan bahwa dirinya ingin fokus dan mendapatkan hasil maksimal dalam pembelajaran (Wawancara dengan Moh. Tripandi tanggal 27 September 2016). Pendapat Tripandi di atas menjadi corong bagi peneliti, bahwa mahasiswa butuh dimotivasi, butuh pendekatan personal, walaupun terkadang melelahkan, namun sebagai dosen maka berbagai gaya dibutuhkan untuk mendorong mengurangi kejenuhan belajar.

Selain itu, menurut Afriana bahwa mereka ingin dosennya murah senyum dengan gaya komunikasi keibuan dan lemah lembut, tapi ibu ini tidak lembut, dia tegas. Bagus juga sih, tapi kami jadi tegang jadinya. Positifnya dan ini menjadi nilai tambah, walau mengantuk dan sudah jenuh belajar kami harus mampu menjadi lebih baik, karena motivasi dosen NU mampu mengubah kebiasaan kami yang lambat mengumpulkan tugas, ditambah lagi, kami suka diajak dosen ke tempat yang ada hubungannya dengan matakuliah Sejarah Sosial, sehingga membuat kami ikut menikmati alam dan suasana masyarakat tempat lokasi penelitian. Misalkan kami di bawa penelitian ke museum, dan masih banyak tempat-tempat yang dapat dikunjungi di sekitar Kota Palu. Ini bagus supaya kami tidak jenuh belajar" (Wawancara dengan Afriana, tanggal 14 September 2016). Dengan demikian dalam pembelajaran diperlukan lingkungan sekitar sebagai sumber belajar, salah satunya museum. Sumber belajar pada dasarnya adalah segala sesuatu (benda, data, fakta, ide, orang, dan lain sebagainya) yang bisa menimbulkan proses belajar. Contohnya, model, realia, maket, museum, pasar dan lain-lain (Prastowo (2018).

Selanjutnya, hasil observasi juga menunjukkan bahwa faktor penyebab kejenuhan belajar matakuliah Sejarah Sosial karena metode pembelajaran yang 
masih kurang variatif mestinya harus ada rekreasi sambil belajar, ini memang dilakukan tapi jarang sekali, selain itu karena perhatian dosen terhadap mahasiswa yang mengalami kejenuhan belajar tersebut belum maksimal. Selain itu perlunya gaya komunikasi antara dosen dan mahasiswa yang sifatnya dapat dua arah. Gaya komunikasi dua arah disini maksudnya, antara mahasiswa dan dosen harus saling mendengarkan keluh kesah dan umpan baliknya.

Melihat faktor penyebab kejenuhan belajar ini, maka penulis menyarankan beberapa hal untuk mengatasi kejenuhan belajar yakni: Dosen harus membangun komunikasi dua arah kepada mahasiswa yang mengalami kejenuhan belajar agar di berikan perhatian khsusus baik dalam mengerjakan tugas maupun di kampus; dosen perlu lebih mengemas pembelajaran dengan ice-breaking/rekreasi sambil belajar; menghindarkan ketegangan saat mengajar; kontrol orang tua walaupun berjauhan, itu sangat penting demi menghindarkan pergaulan negatif mahasiswa di masyarakat, terlebih apabila mahasiswa yang kost. Maka hal yang perlu dilakukan terkait gaya komunikasi untuk mengurangi kejenuhan belajar pada matakuliah Sejarah Sosial, adalah: Belajar sangat perlu meningkatkan metode belajar dengan cara yang bervariasi; mengadakan perubahan gaya komunikasi yang mudah di terima mahasiswa, yakni sedikit lebih rileks dan melakukan pemusatan pembelajaran; menciptakan situasi baru dengan belajar melalui icebreaking/ rekreasi sambil belajar lewat alam atau lingkungan sekitar; menghindarkan ketegangan mental saat belajar. Uraian yang telah dikemukakan di atas, maka ditemukan gaya komunikasi yang perlu dilakukan oleh dosen untuk mengurangi kejenuhan belajar, sebagai berikut:

Menggambarkan gaya komunikasi yang aktif namun tetap mengedepankan kelembutan, mengambil secara penuh inisiatif sosial untuk meningkatkan kemampuan mahasiswa untuk berinisiatif, responsif secara sosial dengan lingkungan sekitarnya, serta mampu mensinergikan pendapatnya dengan dengan mengedepankan jiwa emosional yang terkontrol terhadap mahasiswa.

Gaya komunikasi harus dua arah dengan tidak melepaskan message berupa informasi dengan memperhatikan secara penuh perhatian, Gaya komunikasi dengan memerintah tapi menunjukkan cara dan solusinya, sehingga mahasiswa yang tadinya tidak terukur jadi terukur kemudian secara maksimal dapat mengerjakan tugas dengan baik, melalui pengulangan dan pengulangan kalau melakukan kesalahan, terakhir adalah gaya komunikasi sebagai pendengar yang penuh perhatian, dan membuat keputusan dengan mempertimbangkan semua pihak.

Upaya ini tidak bisa hanya dilakukan sepihak tetapi untuk menciptakan pembelajaran yang kreatif dan menyenangkan dibutuhkan dukungan mahasiswa civitas akademika, orang tua dan masyarakat. Diperlukan pula sebuah lembaga pendidikan yang memiliki strategi dan tindakan yang efektif dan kreatif serta menyenangkan, walaupun belum disertai tingkat pencapaian hasil yang 
memuaskan, jauh lebih "sehat" dan "menjanjikan" jika sebuah lembaga pendidikan yang memiliki tingkat pencapaian hasil yang tinggi, tetapi tidak berdasarkan strategi dan tindakan. Oleh karena itu semua harus bersinergi membangun kerjasama untuk memajukan pendidikan di daerahnya selain dari memiliki kemampuan strategi juga diperlukan gaya komunikasi supportive style, yakni cenderung diam tapi tidak diam, tenang penuh perhatian, menatap mahasiswa dengan perhatian penuh, cenderung menghindari power sebagai pendidik, dan mampu membuat keputusan dengan mempertimbangkan semua argumen dan keinginan mahasiswa walaupun ini sangat sulit dilakukan (Lie, Andriono, \& Prasasti, 2014).

\section{PENUTUP}

Hasil peneitian menunjukkan bahwa gaya komunikasi yang penting dilakukan oleh dosen untuk mengurangi kejenuhan belajar, sebagai berikut: mengembangkan gaya komunikasi aktif namun tetap mengedepankan kelembutan sebagai motivator, mengambil secara penuh inisiatif sosial agar mahasiswa meniru untuk mampu berinisiatif secara sosial dengan lingkungan sosialnya, serta mampu menyatakan pendapat dengan mengedepankan jiwa emosional yang terkontrol, gaya komunikasi harus dua arah dengan mengirim informasi dengan memperhatikan secara full dan penuh perhatian tanpa memihak, gaya komunikasi dengan memerintah tapi menunjukkan caranya, sehingga mahasiswa yang tadinya tidak terukur jadi terukur sehingga secara maksimal dapat mengerjakan tugas dengan baik, melalui pengulangan dan pengulangan kalau melakukan kesalahan, serta gaya komunikasi pendengar, dengan penuh perhatian mendengar dan menyampaikan informasi, dan membuat keputusan dengan mempertimbangkan semua pihak.

Dosen hendaknya berupaya mengoptimalkan gaya komunikasi dalam proses pembelajaran, sehingga dapat menumbuhkembangkan semangat dan kemampuan mahasiswa yang kelak menjadi guru panutan, ketika berkecimpung di tengah-tengah masyarakat, baik sebagai guru, motivator atau inisiator pendidikan di manapun berada. Selain itu diharapkan pula menjadi acuan bagi peneliti lain yang ingin mengungkap gaya komunikasi mengajar sebagai upaya mengatasi kejenuhan belajar mahasiswa.

\section{DAFTAR PUSTAKA}

Arifin, B. (2018). Strategi Komunikasi Dakwah Da’i Hidayatullah dalam Membina Masyarakat Pedesaan. Communicatus: Jurnal Ilmu Komunikasi, 2(2), 159-178. DOI :10.15575/cjik.v2i2.4940 
Giri, V. N. (2006). Culture and communication style. The Review of Communication, 6(1-2),124-130.

https://doi.org/10.1080/15358590600763391.

Haber, S.H., David, M., Kennedy., \& Krasner, S.D. (1997). Brothers under the

Skin: Diplomatic History and International Relations. International

Security, 22(1), 34-43 at p.43. DOI:10.1162/isec.22.1.34

Hakim, T. (2004). Belajar Secara Efektif. Jakarta: Puspa Swara

Hutapea, L. (2016). Gaya Komunikasi Interpersonal Orangtua dalam Mencegah

Penyalahgunaan Narkoba pada Remaja di Desa Cinta Rakyat Kecamatan

Percut Sei Tuan Kabupaten Deli Serdang. Jurnal Al-Balagh, 1(1), 126-137.

http://jurnal.uinsu.ac.id/index.php/balagh/issue/view/77

Lie, Anita., Andriono, Takim., \& Prasasti, Sarah. (2014). Menjadi Sekolah Terbaik:

Praktik-Praktik Strategis dalam Pendidikan. Jakarta: Tanoto Foundation \&

Raih Asa Sukses (Penebar Swadaya Grup).

Liliweri, A. (2011). Komunikasi Serba Ada Serba Makna. Jakarta: Kencana Prenada Media Group.

Mahanani, P.A.R. (2014). Media Sosial dan Gaya Komunikasi: Jurnal Komunikator, 6(1), 60. http://journal.umy.ac.id/index.php/jkm/issue/view/43

Mazaya, M., Setiabudi, D., \& Santosa, H.P. (2013). Pengaruh Gaya Komunikasi dan Kualitas Pelayanan Customer Service terhadap Kepuasan Nasabah (Studi pada Nasabah PT. Bank BNI Syariah Cabang Semarang). Jurnal Interaksi Online, 1(4). https://ejournal3.undip.ac.id/index.php/interaksionline/article/view/3591

Miles \& Huberman. (Terj. Tjetjep Rohendi Rohidi). (2009). Analisis Data Kualitatif (terjemahan). Jakarta: Penerbit UI Press.

Mulyono. (2011). Strategi Pembelajaran: Menuju Efektivitas Pembelajaran di Abad Global. Malang: UIN Malang Pers.

Nuraedah. (2017). Tantangan dan Peluang Pembelajaran Sejarah Lisan Pada Mahasiswa Pendidikan Sejarah di FKIP Universitas Tadulako. Jurnal Historia: Jurnal Pendidik dan Peneliti Sejarah. 1(1), 1-24. https:/ / ejournal.upi.edu/index.php/historia/issue/archive

Prastowo, A. 2018. Sumber Belajar dan Pusat Sumber Belajar. Depok: Kencana.

Rumini, S. (1998). Psikologi Umum. Yogyakarta: FKIP IKIP Yogyakarta

Setyanto, Y. (2011). Gaya Kepemimpinan dan Iklim Komunikasi di Kementerian Pertahanan. Jurnal Komunikasi Universitas Tarumanagara, 3(1).

Sucia, V.(2016). Pengarub Gaya Komunikasi Guru, Komuniti. VIII (2), p-ISSN: $2087-$ 085X, e-ISSN: 2549-5623. DOI: https://doi.org/10.23917/komuniti.v8i5.2942

Sudarman, A. (2018). Strategi Komunikasi untuk Meningkatkan Kesadaran Masyarakat dalam Membayar Zakat Maal. Communicatus: Jurnal Ilmu Komunikasi, 2(1), 39-58. DOI :10.15575/cjik.v2i1.5056 
Mutawakkil \& Nuraedah

Sudiansyah, A. (2017). Efektivitas Komunikasi Dakwah di Pesantren MQ dalam Merubah Akhlak Santri. Communicatus: Jurnal Ilmu Komunikasi, 1(2), 139154. DOI :10.15575/ gijk.v1i2.4842

Sugihartono, (2007). Psikologi Pendidikan. Yogyakarta: UNY Press.

Syah, M. (1999). Psikologi Belajar. Jakarta: PT. Raja Grafindo Persada.

Syah, M.(2011). Psikologi Pendidikan dengan Pendekatan Baru. Bandung: PT. Remaja Rosdakarya.

Teviana, T. (2011). Pengaruh Gaya Kepemimpinan dan Komunikasi Intern terhadap Efektivitas Kerja Pegawai pada RS. Estomihi Medan. Jurnal Keuangan \& Bisnis Program Studi Magister Manajemen Sekolah Tinggi Ilmu Ekonomi Harapan, 3(3).

Tohirin. (2009). Psikologi Pembelajaran Agama Islam. Jakarta: PT. Raja Grafindo Persada. 